\title{
Derde Internasionale Konferensie van Isme
}

Op uitnodiging om 'n referaat te lewer oor "New trends in music education in the Union of South Africa", het ek die voorreg gehad om die hoogs interessante konferensie as die enigste verteenwoordiger uit Suid-Afrika by te woon.

Isme is ' $n$ jong organisasie wat 'n paar jaar gelede in die lewe geroep is om musiekopvoeding in alle lande te bevorder. Dit staan onder voorsitterskap van prof. Domingo Santa Cruz van Chile en het as algemene sekretaris dr. Egon Kraus van Keulen, Duitsland. Verder is die bestuur goed verteenwoordigend van alle lande en rasse van die aardbol.

Die afgevaardigdes, sowat 450 uit 30 verskillende Iande, het alle lae van die musiekopvoeding vanaf die laerskool tot die universiteit verteenwoordig. Isme konfereer al om die derde jaar en dis gebruiklik om iedere keer spesiale aandag aan 'n spesifieke vertakking van die musiek te wy. Vanjaar het die klem op skoolmusiek geval. In hierdie verband is referate deur musiekpedagoge oor onderwerpe soos die volgende gelewer: „Basic concepts of Music education" en ,The preparation of general teachers and music teachers".

Dit wil egter nie sê dat ander vertakkinge soos indiwiduele musiekonderrig en musiekonderwys aan hoër inrigtinge soos konservatoria en universiteite nie voldoende aandag geniet het nie. Inteendeel daar was genoeg voedsel ook vir diegene wat in hoër onderwys belang gestel het. So is daar referate oor die volgende interessante onderwerpe gelewer: „Methods of analysing
Kopenhagen 31 Julie-7 Augustus 1958

contemporary works" deur prof. Mersmann, president van die Duitse musiekraad, asook ,Music in higher education", toegelig deur verskeie sprekers, om maar 'n paar te noem.

Baie van die voordragte, toeligtings en demonstrasies het gelyktydig plaasgevind, sodat 'n mens kon bywoon waarin jy die meeste belangstel. Daarby het gekom 'n baie interessante uitstalling van musiekliteratuur. Ook is gesorg vir 'n aantal hoogstaande musiekuitvoerings van uiteenlopende aard en 'n uitstappie na die pragtige Deense platteland.

Een van die belangrikste resolusies stel in vooruitsig die publikasie van 'n kwartaalblad waarin verdienstelike artikels in ten minste twee belangrike tale sal verskyn. Hierdie blad sal aan alle lede gestuur word en sal ook aan alle musiekinrigtinge beskikbaar gestel word.

Dit is te hope dat Suid-Afrika by die volgende konferensie van Isme in 1961 beter verteenwoordig sal wees. Inskakeling by hierdie liggaam kan alleenlik tot voordeel van ons musiekopvoeding strek en behoort sterk oorweging te geniet van alle instansies wat die bevordering van musiek op die hart dra. Vir meer besonderhede oor hierdie organisasie kan die volgende persoon geraadpleeg word: Dr. Egon Kraus, Manderscheiderstrasse 35, Köln, Deutschland.

M. C. ROODE.

P.U. vir C.H.O.

KOERS 